carried out in Leopoldville, under the direction of M. Lagauche, consultant to a private engineering firm. Based on a detailed classification of jobs prepared for the purpose, the survey produced a very complete account of the rates of salaries and wages paid throughout the area. A report of the survey appears in the Bulletin Mensuel des Statistiques Generales du Congo Belge et du Ruanda-Urundi, August 1953, pp. 261-83. In December 1952-January I953 the Service de la Population Noire organized a survey of African trading in Leopoldville which was planned and carried out by M. P. M. Colin, Administrateur Territorial adjoint. The data collected included details of the number of traders, their ages, ethnic origins and the African labour employed by them. The results were analysed in a report prepared by the Service de la Population Noire entitled: Activites indépendantes à la cité indigène de Léopoldville. Étude faite en collaboration avec le Plan Décennal (Leopoldville, I955, pp. 96).

A population survey, using sampling methods which had already been tried out by I.R.S.A.C. in Ruanda-Urundi, has recently been completed in Leopoldville as part of a scheme which will cover the whole Congo territory. The work is being carried out jointly by the Service des Affaires Indigènes et de la Main-d'œuvre and the Government Statistical Department, under the direction of M. Romaniuk, and includes data on age, origin, family status, education and occupations of the native population. Partial results are being published in the Bulletin Mensuel des Statistiques Générales du Congo Belge et du Ruanda-Urundi. A recent article in Zaire comments on the population figures already published (Fr. Lamal, 'Considérations critiques sur des récents travaux de démographie congolaise', Zaïre, ix. 6, juin 1955). Further researches of this kind are being developed in connexion with the TenYear Plan, and the Department of Administration and Social Sciences of the University of Lovanium may be expected to enter the field also.

In view of the growing importance of Leopoldville with regard to the economic and social conditions of the African worker, research in this area should yield important results.

ANdré Van CaUwenbergh

\title{
Enquête sur le Commerce indigène, Elisabethville
}

LE Centre d'Étude des Problèmes Sociaux Indigènes (CEPSI) propose d'entreprendre une enquête sur le commerce indigène dans le centre extra-coutumier d'Élisabethville. C'est au moment actuel de l'évolution du commerçant noir qu'il convient d'étudier ses attitudes mentales et son comportement social, afin de déterminer l'orientation que prendra l'activité commerciale, d'adopter les mesures propres à favoriser l'épanouissement de cette activité et aussi de parer au danger que peut présenter la méconnaissance des lois économiques. L'hétérogénéité de la population bantoue qui peuple le C.E.C. permet l'examen des comportements des différents groupes ethniques en présence, et de constater si certaines règles communes s'établissent dans la pratique commerciale ou si, au contraire, les usages varient d'un groupe à l'autre. La présence d'un commerce pour indigènes tenu par des Européens et concentré à proximité du C.E.C. a favorisé les contacts entre Européens et Bantous. Ces derniers se sont très vraisemblablement inspirés de leurs méthodes. L'enquête démontrera dans quelle mesure ses méthodes ont été adoptées et comment elles ont été assimilées.

Un questionnaire a été dressé qui servira à cette étude. Établi primitivement en français, il a été traduit en kiswahili et discuté avec un groupe de notables noirs. Tous les commerçants et artisans libres du C.E.C. seront visités, le nombre de ceux-ci étant insuffisant pour permettre un traitement par des sondages. Le questionnaire concerne l'identité de chaque informateur (âge, groupe ethnique, lieu de naissance, origine des parents, état civil, teligion, régime parentelaire coutumier); études (scolarisation etc.); profession à Élisabethville; logement; propriétés; activité commerciale (lieu d'activité, genre d'activité, méthodes de vente, méthodes d'achat, revenus et chiffre d'affaires etc.). (Voir le Bulletin Trimestriel du CEPSI, juin I955.) 